\title{
Diversity of the Transient Outward Potassium Current in Somata of Identified Molluscan Neurons
}

\author{
Elba E. Serrano and Peter A. Getting a \\ Department of Biological Sciences, Stanford University, Stanford, California 94305
}

We have undertaken a quantitative study of the differences in the properties of the fast transient outward current (Acurrent) between identified neurons of 2 species of nudibranch mollusc. Somata from identifiable neurons of Archidoris montereyensis and Anisodoris nobilis were isolated and voltage-clamped with a 2-microelectrode voltage clamp at $11^{\circ} \mathrm{C}$. We examined diversity in the expression of the time- and voltage-dependent properties of A-current by measuring the following parameters: (1) current magnitude, (2) current density, (3) inactivation kinetics, (4) the voltage dependence of steady-state activation and inactivation. We first characterized A-current in each cell type by measuring these parameters for each identified neuron in a series of animals of a given species. The results of these measurements were used to describe the A-current properties of an identified neuron in terms of a mean and SD. The SD measured diversity within the animal population for any given cell type, while the mean values could be compared to measure diversity in the expression of A-current between identified neurons. When we compared mean values for A-current properties between identified neurons of a given species, we did not detect statistically significant differences in the steady-state voltage dependence of activation and inactivation. However, there were statistically significant differences in peak A-current magnitude, density, and inactivation kinetics between identified neurons. We examined differences between the species by comparing the A-current properties of homologous neurons. The major difference between the species was that outward current magnitude and density were significantly greater in Anisodoris than in Archidoris. We conclude that the magnitude and density of A-current differ between identified nudibranch neurons. The neurons also differentially express A-current inactivation kinetics in a cell-specific manner.

\footnotetext{
Received Mar. 16, 1989; revised June 2, 1989; accepted June 8, 1989.

This work was supported by grants from the National Institutes of Health and the Ford Foundation. We wish to thank Drs. Richard Aldrich, Paul Fuchs, Jon Johnson, Brad Jones, and Peter Ruben for helpful discussion and criticism during the preparation of this manuscript. We are also grateful to Dr. Jon Johnson for the use of his electrophysiology setup and Dr. Stuart Thompson for the use of his laboratory during portions of this research.

Correspondence should be addressed to Dr. Elba E. Serrano, Department of Physiology, School of Medicine, University of California, Los Angeles, CA 900241751 .

a Present address: Dr. Peter A. Getting, Department of Physiology and Biophysics, University of Iowa, Iowa City, IA 52242.

Copyright (C) 1989 Society for Neuroscience $0270-6474 / 89 / 114021-12 \$ 02.00 / 0$
}

Voltage-clamp studies of animal and plant cells have demonstrated the presence of numerous ionic conductances that underlie a wide variety of electrical properties expressed by cell membranes. Ion channels may be distinguished on the basis of their voltage and time dependence, their pharmacology, their ion selectivity, and, in some instances, their modulation by intracellular factors (Hille, 1984). The temporal and spatial integration of the currents flowing through these channels results in the characteristic electrical activity of a cell. Thus, in the case of excitable cells, such as neurons, the repetitive firing properties emerge from the activation or expression of multiple ion channels. Differences in the classes of channels, their relative contribution to total current flow, as well as changes in their timeand voltage-dependent properties, all contribute to the diversity observed in membrane excitability. The ionic basis for this diversity has been analyzed for individual cells such as Loligo giant axon (Hodgkin and Huxley, 1952) and gastropod neuron soma (Connor and Stevens, 1971b), and for classes of cells such as crustacean walking leg axons (Connor, 1975), Drosophila longitudinal flight muscles (Salkoff and Wyman, 1981a, b), and turtle hair cells (Art and Fettiplace, 1987). However, little systematic study has been done in quantitatively determining how a given ionic current might vary between cells of the same class within an animal population or between classes of cells (celltype comparison). Nevertheless, a knowledge of the differences in the characteristics of ionic currents between cells is necessary in order to understand processes which regulate ion-channel expression, and ultimately, lead to the observed diversity of cell types as defined by their electrical properties. We therefore systematically studied how the expression of the time- and voltagedependent properties of one conductance, the fast transient potassium current (A-current; $\mathrm{I}_{\mathrm{A}}$ ), varies between identified cells of 2 species of mollusc, Archidoris montereyensis and Anisodoris nobilis. Molluscan preparations provide many advantages for quantitative studies of the origins of diversity between cell types. Giant neurons in the molluscan nervous system are easily identifiable by color and location in the ganglia and due to their size, they are suitable for electrophysiological recordings with the 2 -microelectrode voltage-clamp techniquc. Furthermore, they have the same function, electrical properties, and synaptic connections from animal to animal.

A-current was first described by Hagiwara et al. (1961) in neurons from the esophageal ganglia of Onchidium verruculatum, and since then it has been characterized in membranes from many phyla, including non-neuronal cells (for reviews, see Rogawski, 1985, and Rudy, 1988). The voltage-dependent properties of A-current make it possible to isolate this current by 

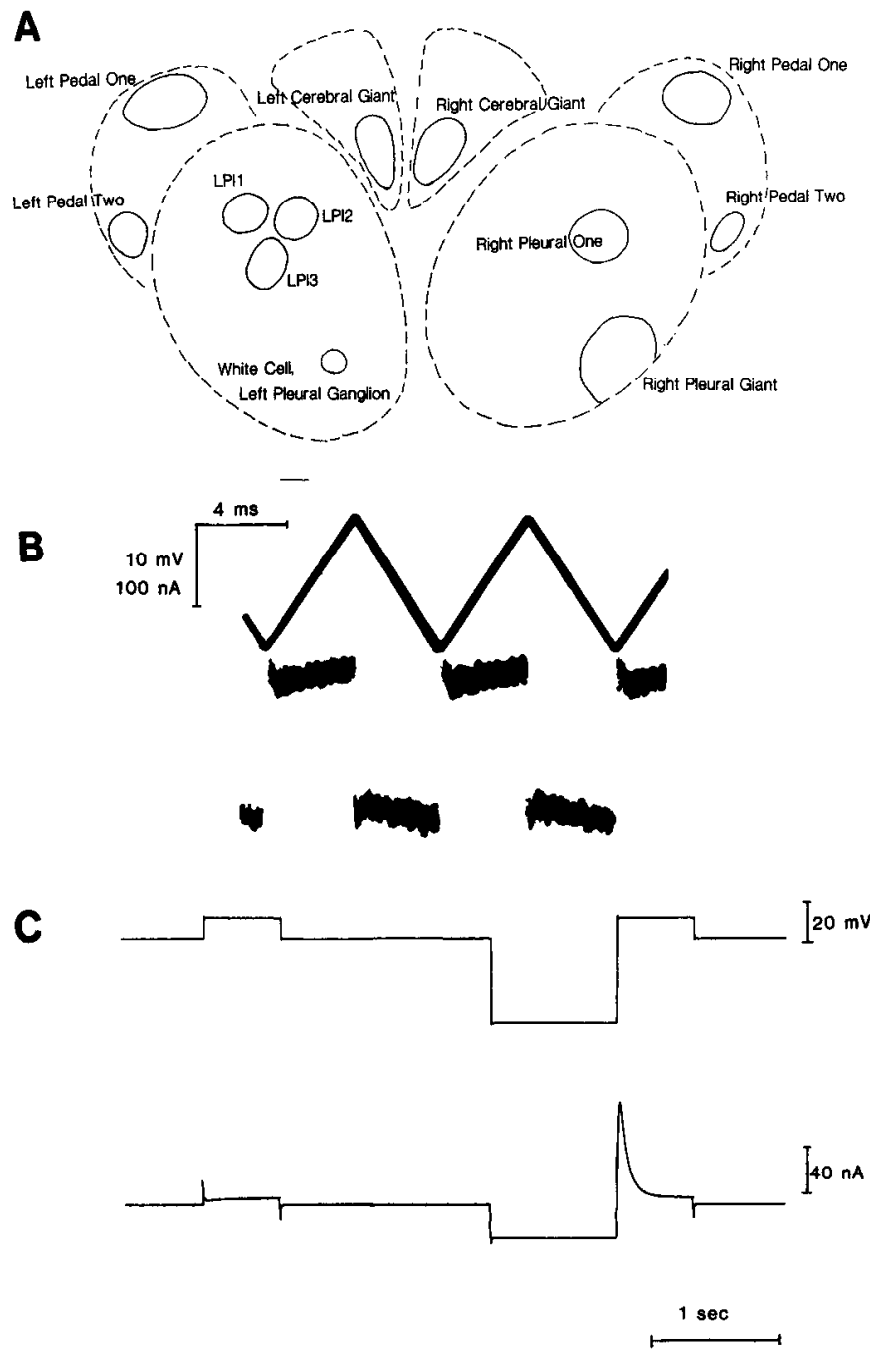

Figure 1. A, Common locations of identified neurons on the dorsal surface of the brain of Archidoris montereyensis. Right Pedal Cell One (RPE1); Right Pedal Cell Two (RPE2); Right Pleural Cell One (RPL1); Right Pleural Giant Cell (RPLG); Right Cerebral Giant Cell (RCG); Left Cerebral Giant Cell (LCG); a small white cell in the left pleural ganglion (WC-LPLG); Left Pedal Cell One (LPE1); Left Pedal Cell Two (LPE2). B, Input capacitance measurement for RPE1. The cell received a triangular wave command, $15 \mathrm{mV}$ in magnitude and with an $8 \mathrm{msec}$ wavelength. The top trace is membrane voltage $\left(\mathrm{V}_{\mathrm{m}}\right)$, and the bottom trace is membrane current. The input capacitance of the cell $(0.021 \mu \mathrm{F})$ was measured using the instantaneous change in membrane current, $I_{\hat{o}}(160 \mathrm{nA})$, and the equation $\mathrm{C}_{\mathrm{m}}=\mathrm{I}_{s}(\mathrm{~W} / 4 \mathrm{~V})$. C, Illustration of the subtraction procedure used to separate $A$-current from other membrane currents. Left trace, A depolarizing test pulse from the holding potential of $-40 \mathrm{mV}$ did not activate an early transient outward current typical of $\mathrm{I}_{\mathrm{A}}$, because activation of A-current requires a hyperpolarizing prepulse. Right trace, A $-80 \mathrm{mV}$ prepulse resulted in activation of a large, transient outward current during the test pulse. The transient current reached a maximum value within $25 \mathrm{msec}$ and decayed to a steadystate level by $500 \mathrm{msec}$. $\mathrm{I}_{\mathrm{A}}$ was measured by manually subtracting the current obtained during a test pulse without a prepulse from that obtained during a test pulse with a prepulse.

voltage paradigms, thereby eliminating the need to separate currents pharmacologically (Connor and Stevens, 1971a; Neher, 1971; Thompson, 1977). The present study was designed to answer the following questions: (1) How do the A-current characteristics of an identified neuron, or cell type, differ from animal to animal? (2) How does A-current differ between identified neurons? and (3) How does A-current differ between species? We resolved the first question by gathering statistical information about the variability in A-current properties for a given cell type within an animal population. We obtained this information by measuring the A-current of each identified neuron in a series of animals of a given species, and describing the A-current properties of the neuron in terms of a mean value with a SD (within population, class comparison). We could then answer the second question by comparing the mean values for A-current parameters between identified neurons (between populations, class comparison). Species differences were determined by comparing the mean A-current values of homologous neurons in the related marine nudibranchs Archidoris montereyensis and Anisodoris nobilis (between species, class comparison).

In this paper we quantitatively compare the time-and voltagedependent properties of A-current between identified neurons of the doridacean nudibranchs Archidoris montereyensis and Anisodoris nobilis. We also present data comparing outward current magnitude and density between these neurons.

\section{Materials and Methods}

Sample population of animals and cells. Specimens of Archidoris montereyensis and Anisodoris nobilis were supplied by Pacific Biomarine, Inc. (Venice, $C A$ ) and ranged in length from 4 to $14 \mathrm{~cm}$. The brain was dissected from the animal and treated with a solution of $0.15 \%$ pronase at $20^{\circ} \mathrm{C}$ (Sigma, Grade B) for 3-5 min to assist in the removal of connective tissue surrounding the brain. After treatment, the brain was rinsed several times with artificial sea water (ASW), refrigerated at $6^{\circ} \mathrm{C}$ for 2-4 hr, and desheathed. A cluster of 3-6 large somata was removed from the neuropil with fine iridectomy scissors using a method similar to that developed by Connor (1977). This cluster of cells was pinned to a Sylgard surface on a Lucite dish and bathed with ASW $(470 \mathrm{mM} \mathrm{NaCl}$, $10 \mathrm{~mm} \mathrm{KCl}, 10 \mathrm{~mm} \mathrm{CaCl}_{2}, 50 \mathrm{~mm} \mathrm{MgCl}_{2}, 20 \mathrm{~mm}$ Tris, pH 7.5) at $11^{\circ} \mathrm{C}$.

The experiments were performed on identified neurons of Archidoris and Anisodoris. The common locations of the giant somata on the dorsal surface of the brain are shown in Figure $1 A$. Cells were identified on the basis of their position, color, size, and location relative to other cells and nerve trunks (Partridge, 1976; Blackshaw, 1979). Studies concentrated on 9 identified cell types: Right Pedal Cell One (RPE1); Right Pedal Cell Two (RPE2); Right Pleural Cell One (RPL1); Right Pleural Giant Cell (RPLG); Right Cerebral Giant Cell (RCG); Left Cerebral Giant Cell (LCG); a small white cell in the left pleural ganglion (WCLPLG); Left Pedal Cell One (LPE1); Left Pedal Cell Two (LPE2).

Electrophysiological recordings. The voltage/current-clamp amplifier used in these experiments was identical to that used by Aldrich et al. (1979). Membrane potential was monitored differentially utilizing an intracellular and an extracellular electrode. Microelectrodes were filled with $3 \mathrm{M} \mathrm{KCl}$ and ranged in resistance from 1 to $5 \mathrm{M} \Omega$. A virtual ground circuit conncetcd to the bath via an agar bridge was used to measure membrane current which was filtered with a second-order Butterworth filter at a low-pass frequency of $2 \mathrm{kHz}$. Series resistance was between 1 and $5 \mathrm{k} \Omega$. Experiments were performed without series resistance compensation. With our values for A-current, this corresponded to errors in voltage of less than $1 \mathrm{mV}$. Records were preserved on a chart recorder (Gould, Inc.) with a low-pass frequency of $50 \mathrm{~Hz}$. Oscilloscope records were filmed when higher frequencies were important.

Healthy, isolated neurons had resting potentials between -35 and $-45 \mathrm{mV}$ and spike amplitudes of 70 to $120 \mathrm{mV}$. Under current clamp, the neurons fired repetitively in response to constant-current pulses and had input resistances ranging between 0.75 and $7.0 \mathrm{M} \Omega$. Control experiments were performed on intact cells in the ganglion to test for the effect of axotomy and isolation on membrane currents. In voltage-clamp experiments conducted on unisolated WC-LPLG, it was possiblc to activate $I_{A}$ without recruiting axon spikes. The properties of $I_{A}$ were not significantly altered in isolated cells from those of WC-LPLG in situ.

Cells received control pulses to monitor $I_{A}$ every $5 \mathrm{~min}$. Data from experiments showing either (1) more than a $5 \%$ change in control current, (2) inward current notches typical of regions of unclamped axon, or (3) more than $3 \mathrm{mV}$ drift in the voltage electrode, were discarded. Some experiments were designed to measure currents during depolar- 
Table 1. Mean peak A-current values for 4 cell types

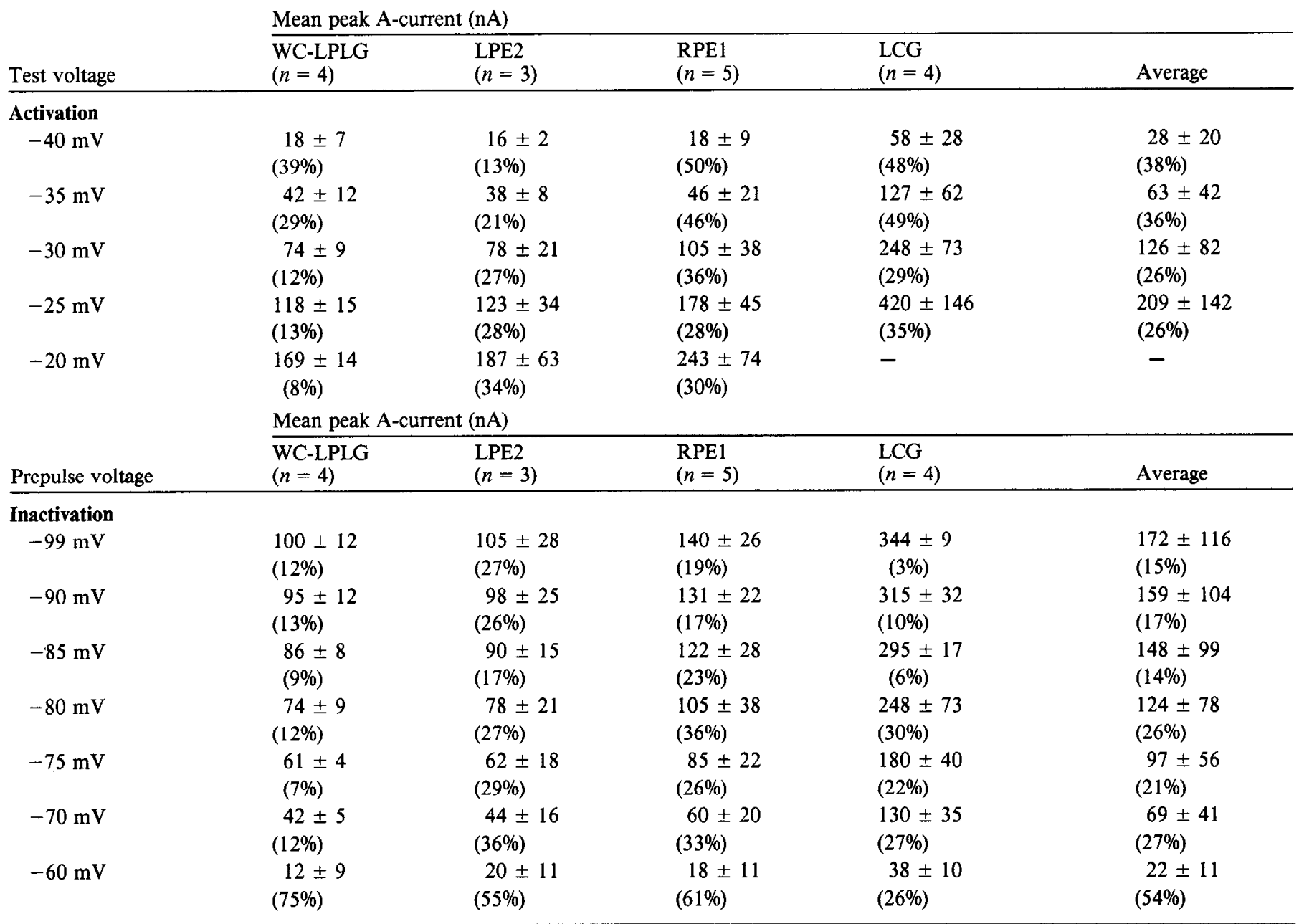

Comparison of A-current magnitude between animals for 4 identified Archidoris neurons. Peak A-current magnitude was measured as a function of activation test

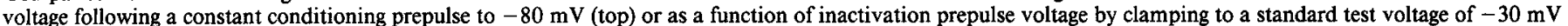

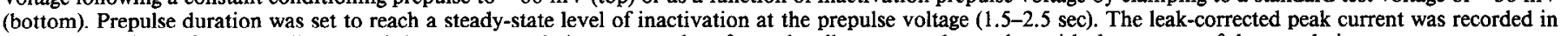
$N$ different animals for each cell type and the average peak A-current values for each cell are entered, together with the average of the population averages.

izations to $0 \mathrm{mV}$. These pulses were delivered from the holding potential of $-40 \mathrm{mV}$ and were a standard $7 \mathrm{sec}$ in duration. Peak outward current measurements from these records were leak corrected prior to analysis. Leak conductances $\left(g_{\mathrm{L}}\right)$ were calculated according to standard procedures (Connor and Stevens, 1971b) and were between 0.1 and $1.4 \mu \mathrm{mhos}$.

Values for current density were determined by normalizing membrane current with measurements of input capacitance $\left(C_{m}\right)$, rather than cell surface area. The input capacitance of cells was measured by applying fast triangular waves under voltage clamp (Adelman and Palti, 1969; Neher, 1971). Since capacity current $\left(I_{c m}\right)$ and membrane voltage $\left(V_{m}\right)$ are related by the expression $I_{c m}=C_{m}\left(\mathrm{dV}_{m} / d t\right)$, capacity current during a triangular wave command voltage is directly proportional to input capacitance. The equation $C_{m}=I_{\delta}(W / 4 V)$, where $I_{\delta}$ is the total instantaneous change in membrane current in $\mathrm{nA}, \mathrm{V}$ is the peak to peak imposed voltage in $\mathrm{mV}$, and $\mathrm{W}$ is the wavelength in seconds, can be used to measure input capacitance (Fig. $1 B$ ). All input capacitance measurements were made with triangular wave frequencies $>100 \mathrm{~Hz}$ and peak-to-peak voltages between 0 and $30 \mathrm{mV}$.

A-current isolation. Previous studies have shown that $\mathrm{I}_{\mathrm{A}}$ can be isolated with voltage paradigms at voltages more negative than $-20 \mathrm{mV}$ (Connor and Stevens, 1971a; Strong, 1984). Figure $1 C$ illustrates the subtraction procedure used to isolate $I_{A}$ by voltage paradigms. Depolarizing test pulses from the holding potential of $-40 \mathrm{mV}$ did not activate an early transient outward current typical of $I_{A}$. Applying a prepulse to $-80 \mathrm{mV}$ prior to the test pulses, however, resulted in activation of a large, transient outward current during the test pulse. The transient current rose quickly to a peak value within $25 \mathrm{msec}$ and decayed to a steady-state level by $500 \mathrm{msec}$. A characteristic feature of all cells was that the steady-state level without prepulse was identical to that with prepulse (Fig. 1C). $\mathrm{I}_{\mathrm{A}}$ was isolated from other currents by manually subtracting the current obtained during a test pulse without a prepulse from that obtained during a test pulse with a prepulse. Analysis of $I_{A}$ parameters was performed on the difference current for all cells in this study. Tail reversal measurements gave A-current reversal potentials between -55 and $-60 \mathrm{mV}$.

Steady-state activation and inactivation curves. Steady-state activation and inactivation curves were obtained by stimulating cells with standard pulse paradigms. Inactivation curves were obtained from values of peak current during a test pulse preceded by hyperpolarizing prepulses delivered from membrane potentials ranging between -100 and $-60 \mathrm{mV}$. Prepulse duration was long enough to reach a steady-state level of inactivation at the prepulse voltage $(1.5-2.5 \mathrm{sec})$. Unless otherwise indicated, the test pulse value for activation of A-current was $-30 \mathrm{mV}$. Steady-state inactivation curves were normalized to the value of peak A-current activated by a prepulse to $-80 \mathrm{mV}$. For steady-state activation curves, cells received a hyperpolarizing prepulse of $-80 \mathrm{mV}$ and $1.5-2.5 \mathrm{sec}$ in duration; test voltages ranged between -50 and $-20 \mathrm{mV}$. Normalized activation curves obtained from peak A-current values were not significantly different from those obtained by extrapolating the decaying phase of $I_{A}$ to 0 time; therefore, activation curves were obtained by normalizing peak current values, rather than extrapolated values, relative to the activated current at $-30 \mathrm{mV}$. Normalized steady-state 
Table 2. Peak $I_{A}$, membrane input capacitance, and A-current density in identified Archidoris neurons

\begin{tabular}{lllll} 
Cell & $N$ & $\begin{array}{l}\mathrm{I}_{\mathrm{A}} \\
(\mathrm{nA})\end{array}$ & $\begin{array}{l}\mathrm{C}_{\mathrm{m}} \\
(\mu \mathrm{F})\end{array}$ & $\begin{array}{l}\mathrm{I}_{\mathrm{A}} / \mathrm{C}_{\mathrm{m}} \\
(\mathrm{nA} / \mu \mathrm{F})\end{array}$ \\
\hline RPL1 & 3 & $100 \pm 20$ & $0.038 \pm 0.013$ & $2800 \pm 450$ \\
& & $(20 \%)$ & $(34 \%)$ & $(16 \%)$ \\
RPE1 & 5 & $\begin{array}{l}110 \pm 40 \\
(36 \%)\end{array}$ & $0.026 \pm 0.004$ & $4200 \pm 880$ \\
& & $(15 \%)$ & $(21 \%)$ \\
LPE1 & 3 & $130 \pm 48$ & $0.026 \pm 0.009$ & $5200 \pm 1900$ \\
& & $(37 \%)$ & $(35 \%)$ & $(37 \%)$ \\
RCG & 3 & $240 \pm 54$ & $0.016 \pm 0.002$ & $14,000 \pm 3100$ \\
& & $(23 \%)$ & $(13 \%)$ & $(22 \%)$
\end{tabular}

Results of experiments determining A-current density in 4 identified neurons. Peak A-current and input $C_{m}$ values were obtained for each identified neuron in $N$ animals and then used to calculate current density by normalizing peak current with input capacitance (peak $I_{A} / C_{m}$ ). These 3 numbers were averaged and their means and $S D s$ are presented. Peak $I_{A}$ values were obtained from activated A-current records at a test potential of $-30 \mathrm{mV}$ following a $1.5-2.5 \mathrm{sec}$ hyperpolarizing prepotential to $-80 \mathrm{mV}$; input capacitance was calculated by applying triangular waveforms to the cells under voltage clamp and measuring the instantaneous change in the current (see Materials and Methods). The variance among the population means ( $F$ statistic) for A-current density was significant at the 0.001 level; the variance in A-current magnitude was significant at the 0.02 level. There were significant differences between the mean A-current density values of RPL1 and RCG $(p<0.01)$, and RPEI and RCG $(p<0.01)$.

activation curves were independent of prepulse voltage for prepulse voltages ranging from -99 to $-75 \mathrm{mV}$. We did not examine the effect on activation curves of prepulse voltages more positive than $-75 \mathrm{mV}$.

Statistics. Unless otherwise indicated, all data are presented as means \pm SD. Linear relationships between variables were established by a least-squares fit to the data. Correlation coefficients were used to evaluate the significance of the linear relationship between the variables. Student's $t$ test was used to determine the significance of the difference between the means when 2 populations were compared in an experiment. The $F$ test was used to evaluate data from 3 or more populations and establish whether the variance among the population treatment means was significant. When a significant overall $F$ statistic was obtained from an experiment, the Tukey honestly significant difference procedure was used to determine significant differences between pairs of means on a post hoc basis. We determined the degree of association between 2 variables by computing the Spearman rank correlation coefficient, $r_{s}$. We used a value of $\alpha=0.01$ for a 1-sided alternative.

\section{Results}

\section{A-current magnitude and density differ between identified} Archidoris neurons

A-current was present in all Archidoris neurons; however, we observed dramatic differences in the magnitude of the current between neurons $(N=104)$. In order to determine the variability in A-current magnitude for an identified neuron within the animal population, we compared the magnitudes of A-current between animals for each cell type. Table 1 summarizes representative peak A-current data from 4 identified Archidoris neurons. These peak values were obtained as a function of test voltage (for activation) following a constant conditioning prepulse to $-80 \mathrm{mV}$ or as a function of prepulse voltage (for inactivation) by clamping to a standard test voltage of $-30 \mathrm{mV}$ (see Materials and Methods). The peak current was recorded in $N$ different animals for WC-LPLG, LPE2, RPE1, and LCG. When we averaged peak A-current values at each test voltage, we observed that within the animal population, the average $\%$ SD of peak A-current for a given cell type was $30 \%$ about the mean value.

This approach was used to establish the average A-current magnitude of each identified neuron within the animal popu- lation and enabled us to compare average values between identified neurons. We noted a 3-fold range in average A-current magnitude between identified neurons. The variance among the population means ( $F$ statistic) for A-current magnitude at the different test voltages was significant at the 0.02 level (Table 1).

Differences in A-current magnitude may be partially attributed to cell size. While 3 of the cells in Table 1 had approximately the same diameter $(\sim 250 \mu \mathrm{m})$, the white cell was much smaller $(\sim 80 \mu \mathrm{m})$. However, the magnitude of the white cell A-current was comparable to that of the other, larger cells. Furthermore, LCG, with a diameter of $250 \mu \mathrm{m}$, had over $2 \frac{1}{2}$ times the A-current of the other neurons. In order to normalize for differences in cell size, it was convenient to have some indication of current density, either by measuring surface area or input capacitance. The diameter of molluscan neurons cannot be used to estimate surface area because of the irregular, flattened shape of the cells and the convolution of the membrane (Coggeshall, 1967). Instead, we measured current density by normalizing A-current magnitude to input capacitance. The underlying assumption was that the specific membrane capacitance was constant among cells; cells with larger input capacitances were presumed to have larger surface areas (Adelman and Palti, 1969; Neher, 1971).

Tables 2 presents the results of experiments determining A-current density in 4 identified neurons. Since it was not possible to determine maximum conductance, we used standard pulse paradigms to activate A-current at a test potential of -30 $\mathrm{mV}$ following a hyperpolarizing prepotential to $-80 \mathrm{mV}$. Once peak A-current and input $C_{m}$ values were obtained, they were used to calculate current density by normalizing peak current to input capacitance (peak $I_{A} / C_{m}$ ). This procedure was repeated for each identified neuron in a total of $N$ animals. Peak $\mathrm{I}_{\mathrm{A}}, \mathrm{C}_{\mathrm{m}}$, and A-current density were averaged and their means and SDs are presented in Table 2. For a given cell type, the average SDs in peak $I_{A}, C_{m}$, and A-current density were 29,24 , and $24 \%$, respectively. Average A-current magnitude ranged from 100 to $240 \mathrm{nA}$. The variance among the population means ( $F$ statistic) for A-current magnitude was significant at the 0.02 level. Furthermore, after current was normalized to input capacitance, there was a 5-fold range in the average A-current density of the 4 identified neurons. The variance among the population means for A-current density was significant at the 0.001 level. There were also significant differences between pairs of means. For example, when the mean A-current density values were compared for cell pairs RPL1/RCG and RPE1/RCG, the differences were significant at the 0.01 level. In conclusion, these results strongly suggest that A-current magnitude and density differ between cell types.

\section{Steady-state activation and inactivation properties are conserved between Archidoris neurons}

We examined differences in the steady-state voltage dependence of activation and inactivation, first, within the animal population for each identified neuron, then between identified neurons. Table 3 compares normalized steady-state activation and inactivation properties between 4 identified Archidoris neurons. Table 3 was constructed by averaging the steady-state activation and inactivation values for each identified neuron for the same animal populations characterized in Table 1. Voltage paradigms were also identical to those used in Table 1. Each entry represents the average of measurements from $N$ animals. When successive measurements were made for a cell type in different 


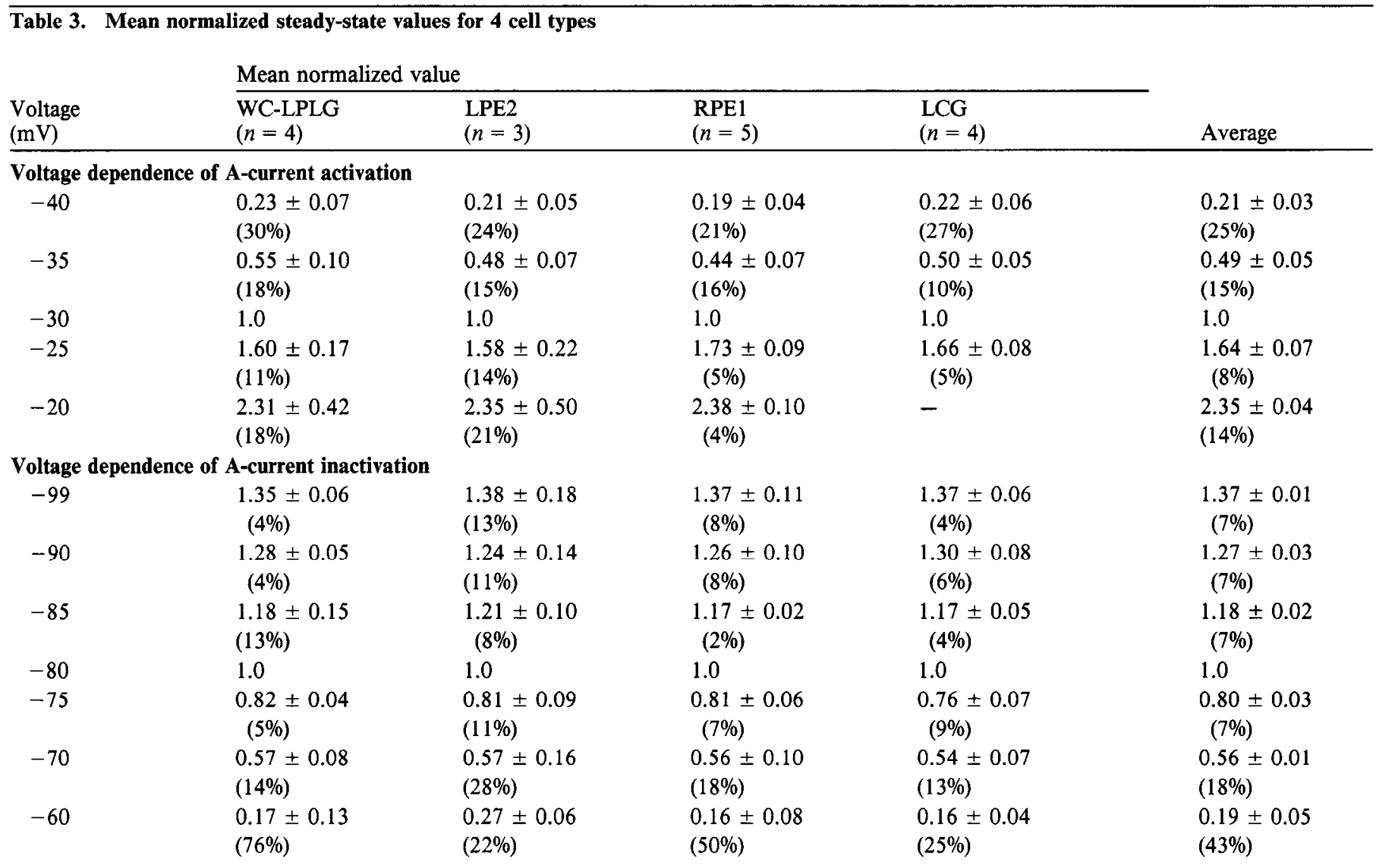

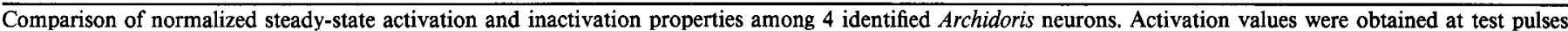

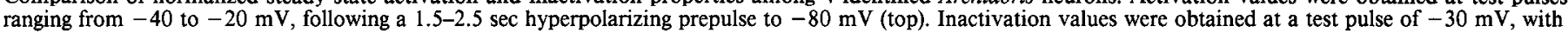

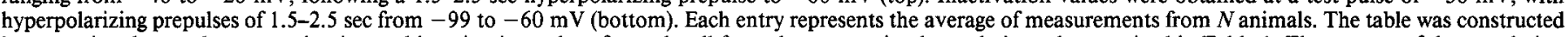

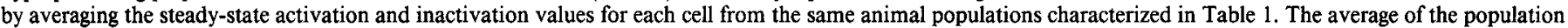

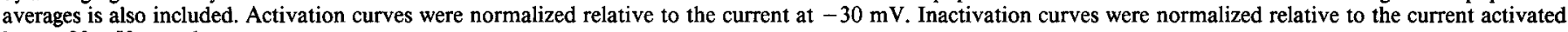
by a $-80 \mathrm{mV}$ prepulse.

animals, the $\%$ SD in the mean values of steady-state voltage dependence of A-current averaged 15\% (Table 3). When the means for the cell types were compared, the variation in the means between cell types averaged $8 \%$ (Table 3 ). Application of the $F$ test to these mean values did not give a significant $F$ statistic. We conclude that there were no cell-specific differences in the steady-state voltage dependence of A-current between identified neurons.

\section{Comparison of inactivation kinetics between Archidoris neurons}

We characterized A-current kinetics by using standard pulse paradigms to measure 2 time constants: the time constant for onset of inactivation $\left(T_{\mathrm{A}}\right)$ and the time constant for removal of inactivation $\left(\mathrm{T}_{\mathrm{REM}}\right)$. The voltage-clamp records in Figure 2 illustrate activated A-current in 2 Archidoris neurons: RPLl (Fig. $2 A$ ) and LCG (Fig. 2B). The decaying phase of the current can be described by a single exponential (Connor and Stevens, 1971a). We determined $T_{A}$ from a least-squares exponential fit of the decay of $\mathrm{I}_{A}$. $T_{A}$ was calculated from steady-state A-current records at a test pulse of $-30 \mathrm{mV}$, following a hyperpolarizing prepulse to $-80 \mathrm{mV}$. Correlation coefficients were always greater than or equal to 0.99 . The time course of removal of inactivation can also be described by a single-exponential process. Figure 3 shows the time dependence of removal of inactivation in RPL1. The duration of the hyperpolarizing prepulse $\left(t_{P P}\right)$ affected the magnitude of the activated $A$-current $\left(\mathrm{I}_{\mathrm{A}-\mathrm{P}}\right)$ until a steady-state condition $\left(\mathrm{I}_{\mathrm{A}-\mathrm{s} s}\right)$ was achieved. The time constant for removal of inactivation, $T_{\text {REM }}$, was calculated from a leastsquares exponential fit of the peak A-current $\left(\mathrm{I}_{\mathrm{A}-\mathrm{P}}\right)$ versus prepulse duration $\left(t_{P P}\right)$ curve. $T_{R E M}$ was calculated from peak $A$-current records at $-30 \mathrm{mV}$ following hyperpolarizing prepulses of variable duration to $-80 \mathrm{mV}$. All correlation coefficients were at least 0.98 . During the course of an experiment, repeated measurements of $T_{A}$ and $T_{\text {REM }}$ varied by $5 \%$ or less. We followed our customary procedure, measuring the time constants for each cell type in several animals, then comparing the means between identified neurons.

Table 4 summarizes the means and SDs for the 2 time constants in 8 identified neurons. Within the animal population, the average $\% \mathrm{SD}$ for $\mathrm{T}_{\mathrm{A}}$ was $10 \%$ for each cell type. $\mathrm{T}_{\mathrm{REM}}$ was slightly more variable, on the average, the $\% \mathrm{SD}$ for $\mathrm{T}_{\mathrm{REM}}$ was $18 \%$. In contrast, there was a statistically significant, 4 -fold range in A-current kinetics between identified neurons. The variance among the population means ( $F$ statistic) was significant at the 0.001 level. There were also significant differences between pairs of means. For example, the difference between the mean $T_{A}$ values for RPL1 (240 $\pm 12 \mathrm{msec} ; N=7)$ and LCG (130 \pm 14 msec; $N=4$ ) was significant at the 0.01 level. Similarly, the difference between the mean $T_{\text {REM }}$ values for RPL1 (700 \pm 170 

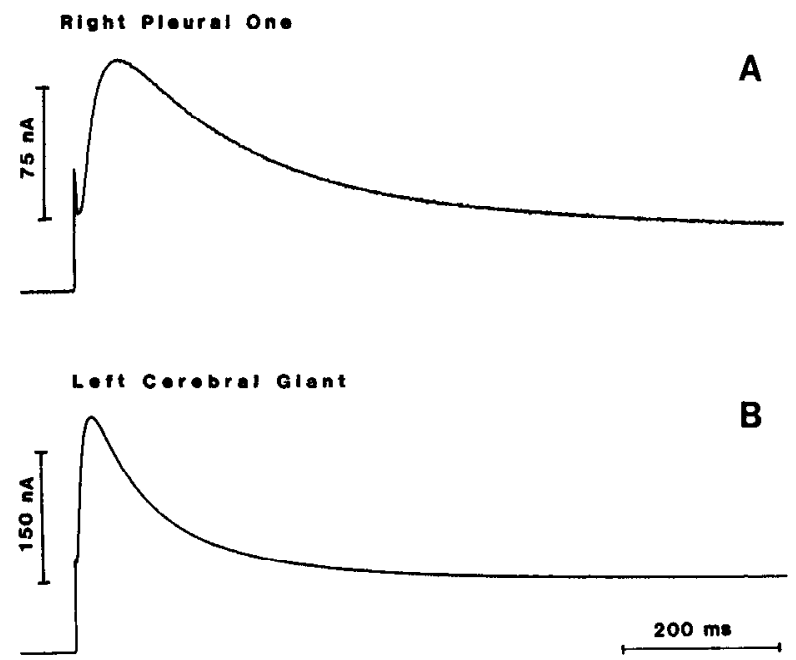

Figure 2. Activated A-current in 2 Archidoris neurons. The decaying phase of the current can be described by a single exponential with a time constant of $T_{A}$. Inactivation was removed with a $2.0 \mathrm{sec}$ hyperpolarizing prepulse to $-80 \mathrm{mV}$. The current was activated by a test pulse to $-30 \mathrm{mV} . A, \mathrm{RPLl}: \mathrm{T}_{\mathrm{A}}=230 \mathrm{msec}, r=0.99 . B, \mathrm{LCG}: \mathrm{T}_{\mathrm{A}}=$ $130 \mathrm{msec}, \mathrm{r}=0.99$.

msec; $N=7)$ and LCG $(270 \pm 64 \mathrm{msec} ; N=4)$ was also significant at the 0.01 level. Representative voltage-clamp records for these 2 cells are presented in Figure 2. $\mathrm{T}_{\mathrm{A}}$ for RPL1 (Fig. $2 A$ ) was $230 \mathrm{msec}$ in this cell, while $\mathrm{T}_{\mathrm{A}}$ for LCG (Fig. $2 B$ ) was $130 \mathrm{msec}$.

We also compared the voltage dependence of $T_{\text {REM }}$ between cells. A-current inactivation was removed more rapidly by large (more negative) hypcrpolarizing prepulses. In Figure $4 A$, the absolute values for $T_{R E M}$ are plotted as a function of prepulse voltage for 3 identified neurons. The test voltage for these experiments was $-30 \mathrm{mV}$; inactivation was removed by pulses of variable duration and ranging in magnitude between -60 and $-100 \mathrm{mV}$. RPL1 had much slower inactivation kinetics than RCG or RPE1. However, when the curves were normalized relative to the $T_{\text {REM }}$ at $-80 \mathrm{mV}$, the voltage dependences of $T_{\text {REM }}$ were similar for all 3 cells, despite different absolute values of $\mathrm{T}_{\mathrm{REM}}$ (Fig. $4 B$ ).

\section{A-current properties of Anisodoris neurons}

We measured the steady-state voltage dependence of activation and inactivation and A-current kinetics in Anisodoris neurons with voltage paradigms identical to those used to study Archidoris. Our results revealed that steady-state properties varied on the average by $15 \%$ for cells of a given type within the animal population. A comparison of the average steady-state values showed differences of $10 \%$ between identified Anisodoris neurons such as RPL1 and LCG (data not shown). As with Archidoris, we noted statistically significant, cell-specific diversity in $\mathrm{T}_{\mathrm{A}}$ and $\mathrm{T}_{\mathrm{REM}}$ between Anisodoris cell types (data not shown). $\mathrm{T}_{\mathrm{A}}$ values ranged from 80 to $350 \mathrm{msec}$ and $\mathrm{T}_{\mathrm{REM}}$ values were between 200 and $1000 \mathrm{msec}$. Representative traces compare features of inactivation between Anisodoris neurons RPL1 (Fig. $5 A$ ) and LCG (Fig. 5C). $\mathrm{T}_{\mathrm{A}}$ was $260 \mathrm{msec}$ in RPL1, $125 \mathrm{msec}$ in LCG. Furthermore, Anisodoris neurons, like Archidoris neurons also exhibited cell-specific differences in current density, the $\operatorname{LCG}(31,000 \mathrm{nA} / \mu \mathrm{F} ; \mathrm{Fig}$. $5 C)$ had 4 times the current density of RPL1 (7100 nA/ $\mu$ F; Fig. $5 A)$.

To summarize, while the steady-state voltage dependence of $\mathrm{I}_{\mathrm{A}}$ did not vary between Anisodoris neurons, there was a cellspecific diversity in A-current density and kinetics. These results paralleled our previous findings comparing A-current properties between Archidoris neurons.

\section{Species comparison of A-current properties}

When we compared peak A-current values from Archidoris neurons with those from Anisodoris neurons, we observed pronounced differences between the 2 species in the distribution of current magnitude. We gathered steady state A-current data at $-30 \mathrm{mV}$ (preceded by hyperpolarizing prepulses to $-80 \mathrm{mV}$ ) and noted that while $54 \%$ of the Anisodoris neurons had a peak $\mathrm{I}_{\mathrm{A}}$ of at lcast $200 \mathrm{nA}(N=20)$, only $7 \%$ of the Archidoris ncurons had currents of similar magnitude $(N=84)$.

In order to compare A-current density across species, peak $\mathrm{I}_{\mathrm{A}} / \mathrm{C}_{\mathrm{m}}$ was graphed as a function of $\mathrm{C}_{\mathrm{m}}$ for Archidoris and Anisodoris (Fig. 6). Input capacitances for cells from the 2 species extended over the same range, between 2 and $38 \mathrm{nF}$. Under the microscope, giant neurons of both species were also similar in size $(100-400 \mu \mathrm{m})$. We observed statistically significant $(p<$ 0.01 ) higher A-current densities in Anisodoris $(14,000 \pm 2200$ $\mathrm{nA} / \mu \mathrm{F} ; N=11)$ than in Archidoris $(5800 \pm 1100 \mathrm{nA} / \mu \mathrm{F} ; N=$
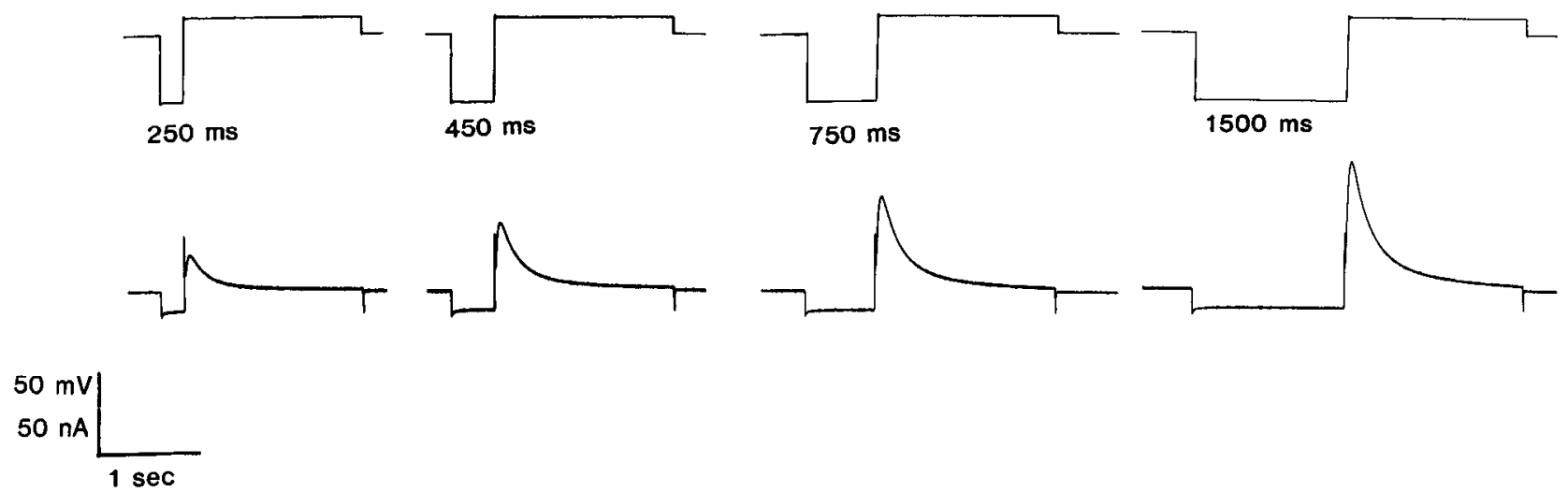

Figure 3. Time dependence of removal of A-current inactivation. RPL1 received prepulses to $-80 \mathrm{mV}$ followed by a test pulse to $-30 \mathrm{mV}$. The duration of the hyperpolarizing prepulse was increased until the peak current reached a steady state. Removal of inactivation was an exponential process with a cell-specific time constant. In this cell, $\mathrm{T}_{\mathrm{REM}}$ was $800 \mathrm{msec}(r=0.98)$. 


\begin{tabular}{lccl}
\hline Table 4. & Diversity of $\mathbf{I}_{\mathbf{A}}$ kinetics in identified Archidoris neurons \\
& $N$ & $\begin{array}{l}\mathrm{T}_{\mathrm{A}} \\
(\mathrm{msec})\end{array}$ & $\begin{array}{l}\mathrm{T}_{\mathrm{REM}} \\
(\mathrm{msec})\end{array}$ \\
Cell & 5 & $65 \pm 7$ & $200 \pm 30$ \\
RPLG & 5 & $(11 \%)$ & $(15 \%)$ \\
& & $69 \pm 8$ & $250 \pm 24$ \\
RPE1 & 9 & $70 \pm 7$ & $(10 \%)$ \\
& & $(10 \%)$ & $230 \pm 37$ \\
LPE1 & 3 & $73 \pm 9$ & $(16 \%)$ \\
& & $(12 \%)$ & $210 \pm 32$ \\
LPE2 & 6 & $100 \pm 8$ & $(15 \%)$ \\
& & $(8 \%)$ & $280 \pm 60$ \\
RCG & 4 & $130 \pm 14$ & $(21 \%)$ \\
& & $(11 \%)$ & $270 \pm 64$ \\
LCG & 5 & $180 \pm 8$ & $610 \pm 140$ \\
& & $(4 \%)$ & $(23 \%)$ \\
WC-LPLG & 7 & $240 \pm 12$ & $700 \pm 170$ \\
& & $(5 \%)$ & $(24 \%)$
\end{tabular}

Summary of the means and SDs for $T_{A}$ and $T_{R E M}$ for 8 identified Archidoris neurons. Time constants were measured in $N$ animals for each cell type using standard pulse paradigms: $T_{A}$ was calculated from A-current records at a test pulse of -30 $\mathrm{mV}$, following a $1.5-2.5 \mathrm{sec}$ hyperpolarizing prepulse to $-80 \mathrm{mV} ; \mathrm{T}_{\mathrm{REM}}$ was calculated from peak A-current records at $-30 \mathrm{mV}$ following hyperpolarizing prepulses of variable duration to $-80 \mathrm{mV}$. There was a statistically significant 4-fold variance in average A-current kinetics between identified neurons ( $F$ test; $p<0.001$ ). The difference between many pairs of means (such as the mean $T_{A}$ and $T_{\text {REM }}$ values for RPLl and RPLG) was significant at the 0.01 level.

12). We also noted a nonlinear trend towards a decrease in current density with increasing input capacitance. Neher (1971) observed a similar correlation in ganglion cells from Helix pomatia. He found that while the fast transient outward currents were found regularly in small to medium-sized ganglion cells $(100-200 \mu \mathrm{m})$, they were small or undetectable in giant cells.

The brain of Anisodoris contains identifiable neurons homologous to those presented in Figure $1 \mathrm{~A}$ for Archidoris. We chose to compare the A-current properties of homologous identifiable neurons in order to more precisely evaluate speciesspecific differences. Representative steady state A-current records from RPLl and LCG in both species are displayed in Figure 5. Cells with similar input capacitances were chosen for comparison. Following removal of inactivation by a hyperpolarizing prepulse to $-80 \mathrm{mV}$, activation of $\mathrm{I}_{\mathrm{A}}$ at $-30 \mathrm{mV}$ resulted in a peak $\mathrm{I}_{\mathrm{A}} / \mathrm{C}_{\mathrm{m}}$ value of $7100 \mathrm{nA} / \mu \mathrm{F}$ for RPL1 in Anisodoris (Fig. $5 A$ ) and $2900 \mathrm{nA} / \mu \mathrm{F}$ for RPLl in Archidoris (Fig. 5B). The corresponding current densities for the LCG were $31,000 \mathrm{nA} /$ $\mu \mathrm{F}$ and 14,000 nA $/ \mu \mathrm{F}$ for Anisodoris (Fig. 5C) and Archidoris (Fig. $5 D$ ), respectively. The A-current densities of homologous neurons were about $2 \frac{1 / 2}{2}$ times as large in Anisodoris as in Archidoris, confirming the observations from the species comparison in Figure 6. When the average steady-state properties of homologous neurons were compared between the 2 spccics (i.e., RPL1, Anisodoris and Archidoris), we noted differences of $10 \%$ or less between the means. We conclude that with our protocol, there were no detectable, statistically significant differences in the steady-state voltage dependence of activation and inactivation either between identified neurons or species. Therefore, the steady-state voltage dependence of $I_{A}$ was conserved between as well as within the species. Finally, we did not detect statistically significant differences in A-current kinetics
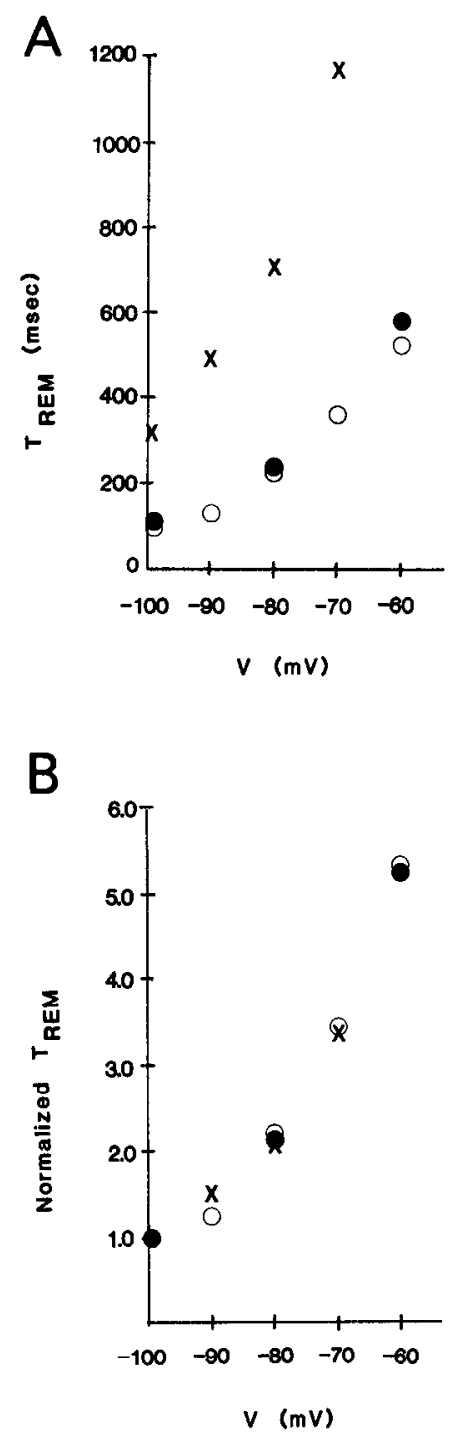

Figure 4. Voltage dependence of removal of inactivation in 3 identified Archidoris neurons. A-current inactivation was removed more rapidly by large (more negative) hyperpolarizing prepulses. The test voltage for these experiments was $-30 \mathrm{mV}$. Inactivation was removed by pulses of variable duration and ranging in magnitude between -60 and -100 $\mathrm{mV}$. $A$, Absolute values for $\mathrm{T}_{\mathrm{REM}}$ are plotted as a function of prepulse voltage for 3 identified neurons. RPL1 had much slower inactivation kinetics than RCG or RPE1. $B$, Normalized $T_{R E M}$ values (data from Fig. $4 A$ were normalized to the value at $-100 \mathrm{mV}$ ) had a similar voltage dependence in all 3 neurons. RPE1 (O), RCG (O), RPL1 (X).

when we compared $\mathrm{T}_{\mathrm{A}}$ and $\mathrm{T}_{\mathrm{REM}}$ values from homologous $A r$ chidoris neurons with those from Anisodoris. Therefore, timedependent features of A-current were preserved between the species, with the corresponding result that A-current kinetics were faster in LCG than in RPL1 in both species.

In conclusion, we found that the major difference between the species was an average higher A-current density in Anisodoris than in Archidoris, based on a comparison of homologous neurons.

\section{Diversity of outward currents of Anisodoris and Archidoris}

Do Anisodoris neurons have larger currents in general or simply more $\mathrm{I}_{\mathrm{A}}$ than Archidoris neurons? In Figure 7, the voltage-clamp records obtained from $7 \mathrm{sec}$ depolarizations to $0 \mathrm{mV}$ from -40 
ANISODORIS

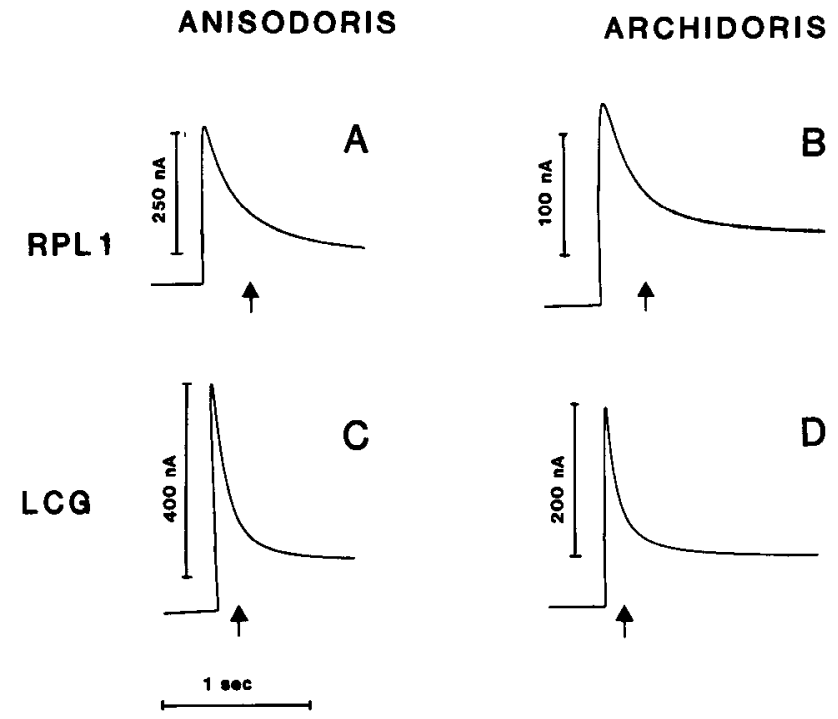

Figure 5. Species comparison of A-current density and kinetics in homologous, identifiable neurons of Archidoris and Anisodoris. Steadystate A-current records from RPL1 and LCG in the 2 species are displayed. Cells with similar input capacitances were chosen for comparison. $I_{A}$ was activated at $-30 \mathrm{mV}$ following removal of inactivation by a hyperpolarizing prepulse to $-80 \mathrm{mV}$. The A-current densities of homologous neurons were at least twice as large in Anisodoris as in Archidoris. Both species exhibited cell-specific differences in current density; the LCG had 4 times the current density of RPLl. The arrows indicate the time required for the current to inactivate to $67 \%$ of the peak value. A-current inactivated twice as fast in LCG as in RPL1. $A$, Anisodoris, RPL1, $\mathrm{C}_{\mathrm{m}}=0.035 \mu \mathrm{F}$, peak $\mathrm{I}_{\mathrm{A}}=250 \mathrm{nA}$, peak $\mathrm{I}_{\mathrm{A}} / \mathrm{C}_{\mathrm{m}}=$ $7100 \mathrm{nA} / \mu \mathrm{F}, \mathrm{T}_{\mathrm{A}}=260 \mathrm{msec}$. $B$, Archidoris, RPL1, $\mathrm{C}_{\mathrm{m}}=0.038 \mu \mathrm{F}$, peak $\mathrm{I}_{\mathrm{A}}=110 \mathrm{nA}$, peak $\mathrm{I}_{\mathrm{A}} / \mathrm{C}_{\mathrm{m}}=2900 \mathrm{nA} / \mu \mathrm{F}, \mathrm{T}_{\mathrm{A}}=230 \mathrm{msec}$. C, Anisodoris, LCG, $C_{m}=0.012 \mu \mathrm{F}$, peak $I_{A}=370 \mathrm{nA}$, peak $I_{A} / C_{m}=31,000 \mathrm{nA} / \mu \mathrm{F}$, $\mathrm{T}_{\mathrm{A}}=125$ msec. D, Archidoris, LCG, $\mathrm{C}_{\mathrm{m}}=0.014 \mu \mathrm{F}$, peak $\mathrm{I}_{\mathrm{A}}=190 \mathrm{nA}$, peak $\mathrm{I}_{A} / \mathrm{C}_{\mathrm{m}}=14,000 \mathrm{nA} / \mu \mathrm{F}, \mathrm{T}_{\mathrm{A}}=130 \mathrm{msec}$.

$\mathrm{mV}$ are compared for homologous cells of the 2 species. At 0 $\mathrm{mV}$ the outward current is a mixture of currents and contains contributions from both $\mathrm{I}_{\mathrm{K}}$, the inactivating outward current, and $I_{C}$, the Ca-activated outward current (Aldrich et al., 1979). The data is for the same neurons presented in Figure 5. Peak outward current density $\left(\mathrm{I}_{\mathrm{p}} / \mathrm{C}_{\mathrm{m}}\right)$ was $71,000 \mathrm{nA} / \mu \mathrm{F}$ in Anisodoris RPL1 (Fig. $7 A$ ), and $24,000 \mathrm{nA} / \mu \mathrm{F}$ in Archidoris RPL1 (Fig. $7 B$ ). Similarly, $\mathrm{I}_{\mathrm{p}} / \mathrm{C}_{\mathrm{m}}$ was $140,000 \mathrm{nA} / \mu \mathrm{F}$ in Anisodoris $\mathrm{LCG}$ (Fig. 7C) and 40,000 $\mathrm{nA} / \mu \mathrm{F}$ in Archidoris LCG (Fig. 7D). While the shape of the delayed outward current trajectory was similar in the homologous cells, the magnitude of the current was much larger in Anisodoris.

We also noted that the outward current trajectories differed dramatically in shape between the cell types in both species. Aldrich et al. (1979) made similar observations, which they attributed to differences in the relative contributions of $I_{K}$ and $I_{C}$ to delayed outward current. In particular, $I_{P}$ contains contributions from both $I_{C}$ and $I_{K}$. In Figure 7, not only did the homologues share similar outward current trajectories, but the current recorded from RPL1 (Fig. 7, $A, B$ ) showed features characteristic of cells with a pronounced contribution from $I_{C}$ to the total outward current (Aldrich et al., 1979). In contrast, the recording from LCG (Fig. 7, C, D) inactivated in a manner typical of a cell whose outward current is predominantly $I_{K}$. Thus, $I_{C}$ may contribute more to total current density in RPL1 relative to $I_{K}$, while $I_{K}$ may have a larger relative current density

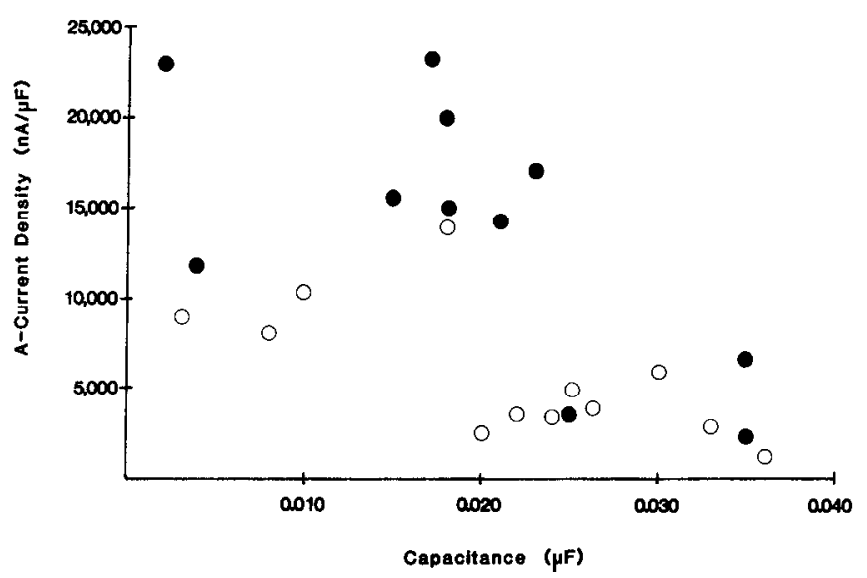

Figure 6. A-current density as a function of input capacitance. In order to compare A-current density between species, peak $\mathrm{I}_{A} / \mathrm{C}_{m}$ was graphed as a function of $\mathrm{C}_{\mathrm{m}}$ for Archidoris and Anisodoris. Peak $\mathrm{I}_{\mathrm{A}}$ was obtained from test pulses to $-30 \mathrm{mV}$ following removal of inactivation by a 1.5 $2.5 \mathrm{sec}$ hyperpolarizing prepulse to $-80 \mathrm{mV}$. There was a statistically significant trend $(p<0.01)$ in Anisodoris $(14,000 \pm 2200 \mathrm{nA} / \mu \mathrm{F}, N=$ 11) towards higher A-current densities than in Archidoris ( $5800 \pm 1100$ $\mathrm{nA} / \mu \mathrm{F}, N=12$ ). Archidoris (O), Anisodoris (๑).

in LCG. Indeed, these observations would support the prediction that $I_{K}$ density and $I_{C}$ density will differ significantly between identified neurons, in a manner analogous to our findings for A-current density (Table 2).

The differences in delayed outward current density and A-current density between the 2 species are presented in Figure 8 . First, peak outward current density $\left(\mathrm{I}_{\mathrm{p}} / \mathrm{C}_{\mathrm{m}}\right)$ was determined for Archidoris and Anisodoris neurons by normalizing peak outward currents from $7 \mathrm{sec}$ depolarizations to $0 \mathrm{mV}$ (delivered from a holding potential of $-40 \mathrm{mV}$ ), with membrane input capacitance. The resulting outward current contains no $I_{A}$, since it was previously inactivated by holding the membrane potential at $-40 \mathrm{mV}$. These values were then plotted against peak $I_{A} / C_{m}$ for the same cell. The majority of the Anisodoris cells fell at a greater distance from the origin than the Archidoris neurons, indicating a larger average current density. The difference between $I_{r}$ densities for Archidoris $(33,000 \pm 12,000 \mathrm{nA} / \mu \mathrm{F} ; N=8)$ and for Anisodoris $(72,000 \pm 11,000 \mathrm{nA} / \mu \mathrm{F} ; N=8)$ was significant at the 0.01 level. Therefore, on the average, Anisodoris cells had a larger peak outward current density at $0 \mathrm{mV}$ than Archidoris, suggesting that other currents, not just $\mathrm{I}_{\mathrm{A}}$, were larger in this species.

Figure 8 also illustrates the wide range in the relative amounts of $I_{p}$ to $I_{A}$. In this graph, the slope of a line from the origin to a given point is equivalent to the ratio $I_{p}: I_{A}$; the points are dispersed within a $60^{\circ}$ arc. In both species, the ratios varied between 18 and 2.6. Furthermore, certain pairs of cells had similar A-current density levels and disparate $I_{P}$ density levels, while other pairs of cells had comparable $I_{P}$ densities and different $I_{A}$ levels. We tested the hypothesis that $I_{P}$ density and $I_{A}$ density varied between cells independent of one another by computing the Spearman rank-correlation coefficient for the 2 species. The $r_{s}$ value was not in the critical region, and we concluded that these were independent variables. Since $I_{p}$ reflected the amount of $I_{C}$ and $I_{K}$ present in the cell (Aldrich et al., 1979), this observation would be consistent with differences in the relative contribution of $I_{K}, I_{C}$, and $I_{A}$, to total current available to the cell at a give voltage. Furthermore, when taken 
RIGHT PLEURAL ONE

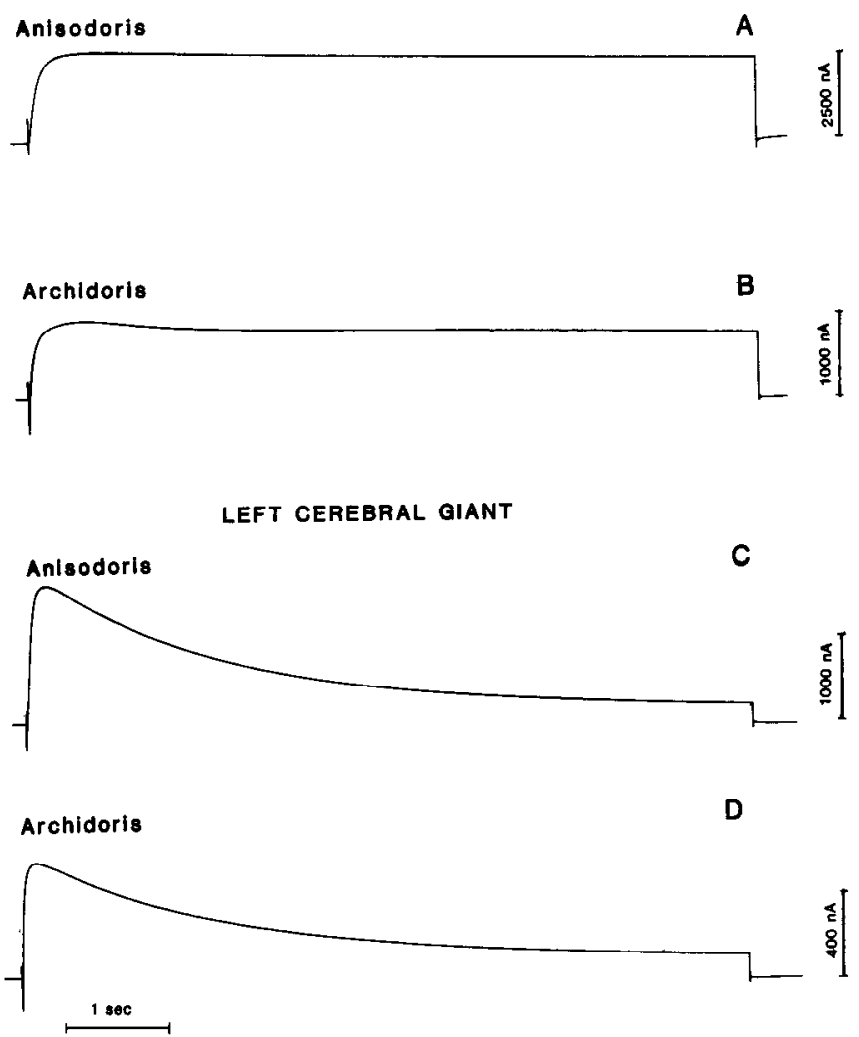

Figure 7. Species comparison of outward currents in homologous, identifiable neurons of Archidoris and Anisodoris. The voltage-clamp records obtained from $7 \mathrm{sec}$ depolarization to $0 \mathrm{mV}$ from a holding potential of $-40 \mathrm{mV}$ are compared for homologous cells of the 2 species. The data are for the identical neurons (i.e., the same animals) presented in Figure 5. While the shapes of the outward current trajectories were similar in the homologous cells, the magnitudes of the currents were much larger in Anisodoris. For measurements of peak outward current density $\left(\mathrm{I}_{\mathrm{p}} / \mathrm{C}_{\mathrm{m}}\right)$, peak outward current $\left(\mathrm{I}_{\mathrm{p}}\right)$ was normalized with cell input capacitance $\left(\mathrm{C}_{\mathrm{m}}\right)$. A, Anisodoris, $\mathrm{RPLl}, \mathrm{C}_{\mathrm{m}}=0.035 \mu \mathrm{F}, \mathrm{I}_{\mathrm{P}}=2500 \mathrm{nA}$, $\mathrm{I}_{\mathrm{P}} / \mathrm{C}_{\mathrm{m}}=71,000 \mathrm{nA} / \mu \mathrm{F}$. B, Archidoris, RPL $1, \mathrm{C}_{\mathrm{m}}=0.038 \mu \mathrm{F}, \mathrm{I}_{\mathrm{P}}=900$ $\mathrm{nA}, \mathrm{I}_{\mathrm{p}} / \mathrm{C}_{\mathrm{m}}=24,000 \mathrm{nA} / \mu \mathrm{F}$. C, Anisodoris, $\mathrm{LCG}, \mathrm{C}_{\mathrm{m}}=0.012 \mu \mathrm{F}, \mathrm{I}_{\mathrm{P}}=$ $1640 \mathrm{nA}, \mathrm{I}_{\mathrm{p}} / \mathrm{C}_{\mathrm{m}}=140,000 \mathrm{nA} / \mu \mathrm{F}$. D, Archidoris, LCG, $\mathrm{C}_{\mathrm{m}}=0.014 \mu \mathrm{F}$, $\mathrm{I}_{\mathrm{p}}=560 \mathrm{nA}, \mathrm{I}_{\mathrm{p}} / \mathrm{C}_{\mathrm{m}}=40,000 \mathrm{nA} / \mu \mathrm{F}$.

together with our other findings, these results predict that the ratio $I_{K}: I_{C}: I_{A}$ should be characteristic of a cell type.

\section{Discussion}

\section{Population differences in the A-current properties of identified} neurons (within population, class comparison)

Our experiments were aimed at establishing the degree of diversity in A-current properties between cell types, based on a comparison of the mean values and SDs obtained from identifiable neurons. The mean and SD were calculated from the results of experiments on the same identifiable neuron in many different animals of a given species. In particular, the SD of a parameter measured diversity within the animal population for any given cell type and could be used to evaluate population differences in the A-current properties of identified neurons. A-current was present in all dorid neurons voltage-clamped in this study.

Certain parameters systematically had a larger \% SD than others. Table 5 summarizes the average \% SD in A-current parameters within the animal population for the identified neu-

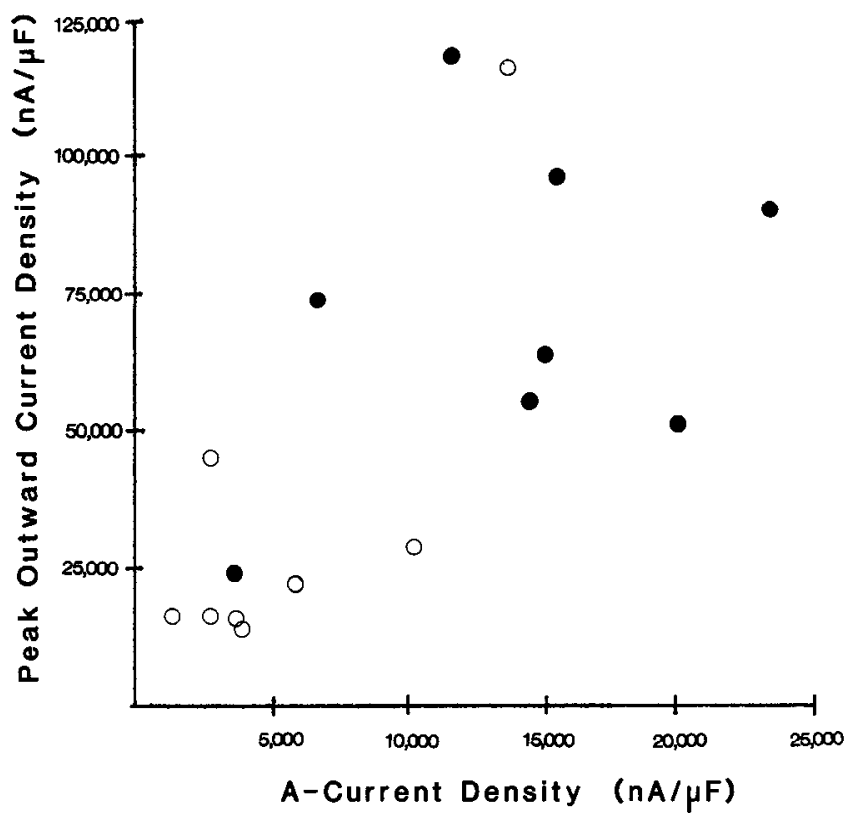

Figure 8. Relationship of peak outward current density to A-current density. Peak outward current was measured from voltage-clamp records obtained from $7 \mathrm{sec}$ depolarizations to $0 \mathrm{mV}$ from a holding potential of $-40 \mathrm{mV}$, and included a correction for leak conductance. Peak outward current density $\left(\mathrm{I}_{\mathrm{p}} / \mathrm{C}_{\mathrm{m}}\right)$ was determined for Archidoris and Anisodoris neurons by normalizing peak outward currents with membrane input capacitance. These values were then plotted against A-current density (peak $I_{A} / C_{m}$ at $-30 \mathrm{mV}$ ) for the same cell. The sample included 8 different identified neurons from each species. The majority of the data for the Anisodoris cells were at a greater distance from the origin than the Archidoris neurons, indicating a larger average peak current density. The difference between mean peak outward current densities for Archidoris $(33,000 \pm 12,000 \mathrm{nA} / \mu \mathrm{F}, N=8)$ and for Anisodoris $(72,000 \pm 11,000 \mathrm{nA} / \mu \mathrm{F}, N=8)$ was significant at the 0.01 level, suggesting that other currents, not just $\mathrm{I}_{\mathrm{A}}$, were larger in Anisodoris neurons. Archidoris (O), Anisodoris (0).

rons. The voltage- and time-dependent properties of A-current showed the least differences within the animal population. When the steady-state voltage dependence of A-current and the time constants for inactivation were measured for the same cell type in different animals of a given species, they showed average \% SD of 15 and $11 \%$, respectively. In contrast, when A-current was activated in the same cell type in a series of animals of a

Table 5. Comparison of \% SD within and between populations

\begin{tabular}{lll} 
& $\%$ SD & \\
\cline { 2 - 3 } Parameter & $\begin{array}{l}\text { Average } \\
\text { within } \\
\text { population }\end{array}$ & $\begin{array}{l}\text { Between } \\
\text { populations }\end{array}$ \\
\hline Peak $\mathrm{I}_{\mathrm{A}}$ & 29 & 82 \\
A-current density & 24 & 77 \\
Steady-state voltage dependence & 15 & 8 \\
$\mathrm{~T}_{\mathrm{A}}$ & 11 & 56 \\
$\mathrm{~T}_{\text {REM }}$ & 20 & 55
\end{tabular}

The average \% SD within the population was calculated by averaging the \% SDs for all cell types for each parameter using the data in Table 2 (Peak $I_{A}, A$-current density), Table 3 (steady-state voltage dependence), and Table $4\left(T_{A}, T_{R E M}\right)$. The $\%$ SD between populations was obtained by calculating the mean and SDs of each parameter using the mean values for the cell types. For example, on the average, for each identified neuron, peak $I_{A}$ varied $29 \%$ from animal to animal in the population. However, when we compared the means of the identified neurons, peak $\mathrm{I}_{A}$ varied by $82 \%$ between populations. 
given species, there were substantial differences in the magnitudes of peak $\mathrm{I}_{\mathrm{A}}$ and A-current density. On the average, A-current density varied by $24 \%$ about the mean for a given cell type as compared with $29 \%$ variability in peak $I_{A}$.

Comparison of A-current properties between identified neurons (between populations, class comparison)

A comparison of mean peak current values established statistically significant differences in the magnitude and density of A-current between identified neurons (Tables 1, 2). While mean peak $I_{A}$ values varied 2 -fold between cell types, A-current density ranged 5-fold, from 2800 to $14,000 \mathrm{nA} / \mu \mathrm{F}$, between identified neurons. The difference between the mean values of current density of pairs of cells, such as RPE1 and RCG, was significant at the 0.01 level. One important conclusion from this result is that cell types differ in the amount of $\mathrm{I}_{\mathrm{A}}$ (or A-current density) available to the cell.

We did not observe statistically significant differences in the steady-state voltage dependence of A-current between cell types (Table 3). In contrast, the time course of conductance changes differed dramatically between dorid neurons. There was a 4-fold range in A-current kinetics as characterized by the inactivation time constants $T_{A}$ and $T_{\text {REM }}$ (Table 4). We did not measure activation kinetics because of the difficulties in measuring the exact value of the time constant for the rising phase of the current (Neher, 1971). However, the observation that the time to peak varied between identified neurons in parallel with the time course of inactivation (Fig. 2) is consistent with the possibility of cellspecific differences in A-current activation kinetics. The time to peak in Archidoris RPL1 (Fig. $2 A$ ) was approximately 50 mscc, as compared with $30 \mathrm{msec}$ in Archidoris LCG (Fig. 2B). The corresponding values for $T_{A}$ (A-current inactivation) in these 2 cells were 230 and $130 \mathrm{msec}$, respectively. The finding that the time constants for activation and inactivation of A-current covary in dorid neurons with changes in temperature (Connor and Stevens, 1971a) is also in accord with the prediction that cells with relatively slow inactivation kinetics will have slow activation kinetics as well.

It is important to recognize that, although the inactivation voltage dependence of A-current was well characterized in these experiments, activation was only examined in a restricted voltage domain. The presence of additional conductances at potentials more positive than $-20 \mathrm{mV}$ made it possible to isolate A-current in only a limited range of voltages, and thus precluded measurements of maximum A-conductance. It is conceivable that if activation were measured at more positive voltages, there could be differences in the steady-state voltage dependence of A-current activation between identified neurons. In our experiments, we also did not examine the foot of the activation/ inactivation curves in detail because as the test voltage approached reversal potential, current amplitudes were both reduced and more sensitive to small fluctuations in reversal potential, making such experiments technically more difficult. Nevertheless, Partridge and Connor (1978) have shown that characteristics of the foot of the curves, such as the degree of overlap and the steepness of the voltage dependence of inactivation, are important in modulating fring frequency, and consequently this deserves further study.

It may seem surprising that the steady-state voltage dependence of A-current was invariant between cells, while the kinetics were not. However, there is evidence for this independent behavior from other experiments. Partridge and Connor (1978) studied the temperature dependence of A-current in Archidoris and Anisodoris. Their results show that as temperature increases, A-current inactivates more rapidly while its magnitude simultaneously increases. There are no concomitant changes in the steady-state voltage dependence of A-current or cell repetitive firing. They conclude that in these neurons, features of the temperature dependence of the A-current system function as an effective buffer to conserve repetitive firing patterns when the organism is exposed to fluctuations in temperature. In addition, Strong (1984) showed that the application of forskolin and R0201724 to Aplysia bag cell neurons accelerated inactivation time constants for A-current. The steady-state voltage dependence of A-current remained unaltered by these drugs.

\section{Outward currents in Archidoris and Anisodoris (between species, class comparison)}

Features of A-current diversity were comparable in the 2 dorid species. In both, the steady-state voltage dependence of A-current did not exhibit statistically significant differences between cells, and in both there were dramatic, significant differences in A-current density and kinetics between cell types. A comparison of homologous identified neurons from Archidoris and Anisodoris revealed that the steady-state voltage dependence of A-current, A-current kinetics (Fig. 5) and even the shape of outward current voltage-clamp records at $0 \mathrm{mV}$ (Fig. 7) were similar in the 2 species. The major difference between the species was that A-current density was $2 \frac{1}{2}$ times greater in Anisodoris than in Archidoris (Fig. 5). Furthermore, in addition to A-current, other outward currents were larger in Anisodoris than in Archidoris. Peak outward current density at $0 \mathrm{mV}$ was, on the average, over twice as large in Anisodoris as in Archidoris (Figs. 7, 8).

A comparison of steady-state activation and inactivation curves for dorid neurons with those from other species suggests that the voltage dependence of A-current can vary between preparations (Rudy, 1988). Dekin and Getting (1987) present evidence for 3 classes of neurons in brain-stem slices from the ventral part of the nucleus tractus solitarius of the guinea pig, based on the presence of 3 kinds of firing patterns. The patterns of repetitive activity correlate with differences in the voltage dependence of A-current. In addition, the A-channels characterized by Solc et al. (1987) in cultured Drosophila myotubes are very different from those of cultured Drosophila neurons. The myotube channels are faster than the neuronal channels, have a larger steady-state component, and have right-shifted activation/inactivation curves with a greater overlap at the foot of the curves. The voltage dependence of the A-current of dorid neurons resembles that of cultured Drosophila neurons rather than the Drosophila myotubes. Indeed, Iverson et al. (1988) propose that differences in the voltage dependence of activation and inactivation may prove useful in categorizing A-channel types. Finally, Connor (1978) observed that the time course of A-conductance changes in crustacean axon was faster than in molluscan somata. Since our experiments were confined to measurements of A-current in molluscan soma, they may not reflect the properties of the channel in the axon.

\section{What are the possible sources of diversity for A-current properties?}

The mechanisms underlying the differences in A-current properties between dorid neurons are unknown at present. However, the diversity we observed in A-current properties could be the result of processes which contribute to cell differentiation during 
development. Such diversity would also be influenced by genetic differences, the developmental stage of the animal and environmental adaptation. Some of these contributions to diversity could be reduced with the use of an isogenic population, raised in a constant, controlled environment and examined at precisely the same stage of development, criteria not fulfilled in these experiments; our sample population of animals was collected over a $1 \frac{1 / 2}{2}$ year period from different marine habitats and contained animals of varying size and age.

Diversity in A-current density between identified neurons could be explained by differences in unit A-channel conductance or A-channel density between cells. The unit A-channel conductance has been determined only in a few preparations, with various results. Experiments have given values of 5-8 and 12$16 \mathrm{pS}$ in cultured neurons and myotubes from wild-type Canton-S Drosophila (Solc et al., 1987), $14 \mathrm{pS}$ in Helix aspersa neurons (Taylor, 1987), $22 \mathrm{pS}$ in rat nodose neurons (Cooper and Shrier, 1985 ) and $40 \mathrm{pS}$ in Lymnaea neuron soma (Kazachenko and Geletyuk, 1984). Although these values extend over a 5 -fold range, there is no report of large differences in unit channel conductance within a preparation. While changes in unit channel conductance alone could account for differences in current density, it may be more plausible to expect the large differences in current density to be due to the numbers of channels inserted, or a combination of both factors. If the differences in current density are due to variable channel density, regulation of channel formation or insertion into the membrane may be important underlying mechanisms.

A possible explanation for the differences in A-current density between the species is that they are an environmental adaptation to different ambient temperatures. Partridge and Connor (1978) observed that A-current magnitude increased with temperature. Divers from the supplier (Pacific Biomarine, Inc.) noted that Archidoris preferred habitats with slightly warmer temperatures than Anisodoris. Thus, the actual current densities of the 2 species may be similar, if measured at their habitat temperature.

Recent advances in our understanding of the processes which affect channels and membranes may have important implications for the striking, 4-fold differences we observed in A-current kinetics between neurons. First, differences in kinetics may reflect immediate membrane environment, unique to each cell. Thus, the channel may be responding to local membrane fluidity or interacting with adjacent molecules. Second, channel properties may be modulated by cytoplasmic factors. Calcium (Salkoff, 1983; Alkon, 1984) and cAMP (Strong, 1984) have been shown to have effects on A-current. Finally, the results of experiments on neurons and muscle of Drosophila combining the techniques of genetics, electrophysiology, and molecular biology point to another explanation: the diversity may be attributed to intrinsic differences in the A-channels and may be the result of mechanisms that determine how genes for the channel are expressed in the membrane. Voltage-clamp studies of Drosophila flight muscle show the early appearance of A-current in developing muscle (Salkoff and Wyman, 1981a). Drosophila Shaker mutations affect A-current properties (Salkoff and Wyman, 1981b; Salkoff, 1983; Wu et al., 1983) and specifically, inactivation kinetics (Salkoff and Wyman, 1981b). The Shaker locus has been successfully cloned (Baumann et al., 1987; Kamb et al., 1987; Papazian et al., 1987; Tempel et al., 1987) and recently, Timpe et al. (1988a, b) and Iverson et al. (1988) have shown that Xenopus oocytes injected with mRNA transcribed from Drosophila Shaker cDNA clones produce functional A-type potassium channels with different inactivation kinetics but with the same voltage dependence of activation and inactivation. The results of our analysis of A-current diversity in situ parallel these findings, because identified neurons differ in kinetics but not in steady-state properties, suggesting that there may be a correlation between mechanisms underlying A-channel diversity in Drosophila and in the molluscan nervous system. The physiological significance of the results of the molecular analysis of potassium channels may perhaps be elucidated by examining A-current expression in these giant molluscan neurons.

In conclusion, during differentiation, the kinds, numbers, properties, and locations of membrane constituents would be under regulation and ultimately result in the characteristic features of a cell. In the case of neurons, differences in membrane cxcitability based on a unique complement of channels, receptors, and transporters, can lead to diverse firing patterns and synaptic activity. Emerging properties of channel and receptor genomes suggest gene duplication as an important mechanism for the establishment of different channel types, based on the level of structural homology between the sodium channel and the AChR (Salkoff and Tanouye, 1986). Posttranscriptional modification and alternative splicing could also result in differences by altering channel proteins at crucial sites, thereby generating ion-channel diversity (Leff et al., 1986; Iverson et al., 1988; Schwarz et al., 1988). With the present technology, such issues as how cells differentiate during development may be resolved at multiple levels, from the genome to the membrane and processes governing channel formation and diversity may be better understood. In particular, identifiable molluscan neurons such as those found in Archidoris montereyensis and Anisodoris nobilis may provide a useful model system for understanding the origins of systematic, regulated differences between neurons.

\section{References}

Adelman, W. J., Jr., and Y. Palti (1969) Voltage clamp measurements of membrane conductance and capacity by oscillating potential control. Fed. Proc. 28: 333.

Aldrich, R. W., Jr., P. A. Getting, and S. H. Thompson (1979) Inactivation of delayed outward current in molluscan neurone somata. J. Physiol. (Lond.) 291: 507-530.

Alkon, D. L. (1984) Calcium-mediated reduction of ionic currents: A biophysical memory trace. Science 226: 1037-1045.

Art, J. J., and R. Fettiplace (1987) Variation of membrane properties in hair cells isolated from the turtle cochlea. J. Physiol. (Lond.) 385: 207-242.

Baumann, A., I. Krah-Jentgens, R. Muller, F. Muller-Holtkamp, R. Seidel, N. Kecskemethy, J. Casal, A. Ferrus, and O. Pongs (1987) Molecular organization of the maternal effect region of the Shaker complex of Drosophila: Characterization of an $\mathrm{I}_{\mathrm{A}}$ channel transcript with homology to vertebrate $\mathrm{Na}^{+}$channel. EMBO J. 6: 3419-3430.

Blackshaw, S. E. (1979) Dye injection and electrophysiological mapping of giant neurons in the brain of Archidoris. Proc. R. Soc. London [Biol.] 192: 421-437.

Coggeshall, R. E. (1967) A light and electron microscope study of the abdominal ganglion of Aplysia californica. J. Neurophysiol. 30: 12631287.

Connor, J. A. (1975) Neural repetitive firing: A comparative study of membrane properties of crustacean walking leg axons. J. Neurophysiol. 38: 922-932.

Connor, J. A. (1977) Time course separation of two inward currents in molluscan neurons. Brain Res. 119: 487-492.

Connor, J. A. (1978) Slow repetitive activity from fast conductance changes in neurons. Fed. Proc. 37: 2139-2145.

Connor, J. A., and C. F. Stevens (1971a) Voltage clamp studies of a transient outward membrane current in gastropod neural somata. J. Physiol. (Lond.) 213: 21-30.

Connor, J. A., and C. F. Stevens (1971b) Prediction of repetitive firing 
behavior from voltage clamp data on an isolated neurone soma. J. Physiol. (Lond.) 213: 31-53.

Cooper, E., and A. Shrier (1985) Single-channel analysis of fast transient potassium currents from rat nodose neurons. J. Physiol. (Lond.) 369: 199-208.

Dekin, M. S., and P. A. Getting (1987) In vitro characterization of neurons in the ventral part of the nucleus tractus solitarius. II. Ionic basis for repetitive firing patterns. J. Neurophysiol. 58: 215-229.

Hagiwara, S., K. Kusano, and N. Saito (1961) Membrane changes of Onchidium nerve cell in potassium-rich media. J. Physiol. (Lond.) 155: $470-489$.

Hille, B. (1984) Ionic Channels of Excitable Membranes, Sinauer, Sunderland, MA.

Hodgkin, A. L., and A. F. Huxley (1952) A quantitative description of membrane current and its application to conduction and excitation in nerve. J. Physiol. (Lond.) 117: 500-544.

Iverson, L. E., M. A. Tanouye, H. A. Lester, N. Davidson, and B. Rudy (1988) A-type potassium channels expressed from Shaker locus cDNA. Proc. Natl. Acad. Sci. 85: 5723-5727.

Kamb, A., L. E. Iverson, and M. A. Tanouye (1987) Molecular characterization of Shaker, a Drosophila gene that encodes a potassium channel. Cell 50: 405-413.

Kazachenko, V. N., and V. I. Geletyuk (1984) The potential-dependent $\mathrm{K}^{+}$channel in molluscan neurones is organized in a cluster of elementary channels. Biochim. Biophys. Acta 773: 132-142.

Leff, S. E., M. G. Rosenfeld, and R. M. Evans (1986) Complex transcriptional units: Diversity in gene expression by alternative RNA processing. Annu. Rev. Biochem. 55: 1091-1117.

Neher, E. (1971) Two fast transient current components during voltage clamp on snail neurons. J. Gen. Physiol. 58: 36-53.

Papazian, D. M., T. L. Schwarz, B. L. Tempel, Y. N. Jan, and L. Y. Jan (1987) Cloning of genomic and complementary DNA from Shaker, a putative potassium channel gene from Drosophila. Science 237: 749-753.

Partridge, L. D. (1976) A note on the anatomy of the circumesophageal ganglion complex of several doridacean nudibranchs. Veliger 15:349351 .

Partridge, L. D., and J. A. Connor (1978) A mechanism for minimizing temperature effects on repetitive firing frequency. Am. J. Physiol. 234: 155-161.
Rogawski, M. A. (1985) The A-current: How ubiquitous a feature of excitable cells is it? Trends Neurosci. 8: 214-219.

Rudy, B. (1988) Diversity and ubiquity of K channels. Neuroscience 25: 729-749.

Salkoff, L. (1983) Drosophila mutants reveal two components of fast outward current. Nature 302: 249-251.

Salkoff, L., and M. A. Tanouye (1986) Genetics of ion channels. Physiol. Rev. 66: 301-329.

Salkoff, L., and R. Wyman (1981a) Outward currents in developing Drosophila flight muscle. Science 212: 461-463.

Salkoff, L., and R. Wyman (1981b) Genetic modification of potassium channels in Drosophila Shaker mutants. Nature 293: 228-230.

Schwarz, T. L., B. L. Tempel, D. M. Papazian, Y. N. Jan, and L. Y. Jan (1988) Multiple potassium-channel components are produced by alternative splicing at the Skaker locus in Drosophila. Nature 331: 137-142.

Solc, C. K., W. N. Zagotta, and R. W. Aldrich (1987) Single-channel and genetic analyses reveal two distinct A-type potassium channels in Drosophila. Science 236: 1094-1098.

Strong, J. A. (1984) Modulation of potassium current kinetics in bag cell neurons of Aplysia by an activator of adenylate cyclase. J. Neurosci. 4: 2772-2783

Taylor, P. A. (1987) Selectivity and patch measurements of A-current channels in Helix aspersa neurones. J. Physiol. (Lond.) 388: 437447.

Tempel, B. L., D. M. Papazian, T. L. Schwarz, Y. N. Jan, and L. Y. Jan (1987) Sequence of a probable potassium channel component encoded at Shaker locus of Drosophila. Science 237: 770-775.

Thompson, S. H. (1977) Three pharmacologically distinct potassium channels in molluscan neurones. J. Physiol. (Lond.) 265: 465-488.

Timpe, L. C., Y. N. Jan, and L. Y. Jan (1988a) Four cDNA clones from the Shaker locus of Drosophila induce kinetically distinct A-type potassium currents in Xenopus oocytes. Neuron 1: 659-667.

Timpe, L. C., T. L. Schwarz, B. L. Tempel, D. M. Papazian, Y. N. Jan, and L. Y. Jan (1988b) Expression of functional potassium channels from Shaker cDNA in Xenopus oocytes. Nature 331: 143-145.

Wu, C. F., B. Ganetzky, F. N. Haugland, and A. X. Liu (1983) Potassium currents in Drosophila: Different components affected by mutations of two genes. Science 220: 1076-1078. 